\title{
SASKATCHEWAN BIRD BANDERS* WILLIAM I. LYON and H. E. MCARTHUR
}

\section{by C. Stuart Houston, 863 University Drive, Saskatoon}

In 1936 and 1937, William Isaac Lyon visited Saskatchewan, accompanied by his friend and fellow bander, H. E. McArthur, also of Waukegan, Illinois. Their efforts resulted in some 85 interesting recoveries.

In 1936, after banding marsh birds at Delta, Manitoba late in June, they banded Marbled Godwits 25 miles east of Yorkton on July 1. The next day they banded four Marsh Hawks, a Killdeer and two Willets near Indian Head; on July 4 at Last Mountain Lake, 61 Ring-billed Gulls and 52 Common Terns; the next day near Elstow, two more godwits. On July 6 and 8, at Redberry Lake, they banded 151 White Pelicans, 96 Double-crested Cormorants, 292 California Gulls and, reportedly, three Lark Sparrows(?). Following this, they banded Franklin's Gulls and Forster's Terns at Murray Lake near Cochin; totals for Delta and Cochin combined were 1002 Franklin's Gulls and 23 Forster's Terns for the two provinces. Lyon's total of all species for Saskatchewan and Manitoba was 1361 individuals and MeArthur's was 546.

In 1937 Lyon and McArthur spent June 30 at Netley Marsh and July 1 at Delta, Manitoba, before reaching Chael Marsh near Henribourg, Saskatchewan, on July 4. There Lyon banded 230 Franklin's Gulls; the next day, 47 more at Waterhen Marsh near Kinistino. On July 6 and 7 , Lyon caught one Gadwall and one White-winged Scoter as they flushed from their nests, and banded 157 pelicans, 52 cormorants, 47 Common Terns and 151 California Gulls. On July 8, they were at Lavoy, Alberta and the next day at Mundare and Egg Lake near Morinville, concluding with eight Bank Swallows at Radium, British Columbia, on July 13. Species totals for McArthur are not available, but in 13

* No. 11 in a series of biographies of bird banders. days in four Canadian provinces his total was 268 individuals banded, while Lyon banded 1317 individuals.

From his Waukegan aviary, Lyon also carried out some interesting experiments concerning the homing abilities of the Brown-headed Cowbird. In 1937 he shipped 149 male cowbirds, trapped at Waukegan, Illinois, to five Canadian cities - Quebec, Toronto, Winnipeg, Regina and Edmonton. Some of these birds had been used previously in similar experiments within the United States: e.g., a cowbird trapped at Waukegan on April 13, 1937 was released at Denver, Colorado April 28, whence it returned to Waukegan on May 23, 1937, only to be shipped the next day to Quebec City!

Thirty male cowbirds were shipped from Waukegan to Regina, Saskatchewan on May 8, 1937, and released there on May 10 and May 11. One bird, 34-248720, returned to Waukegan the same year, on either May 31, 1937 (the date on the computer printout) or on June 16, 1937 (the date in Ottawa C.W.S. files). The following year, the first to be retrapped was 34-248599 on April 16, 1938, followed by $34-248462$ on May 4; both received another free trip and were released in Vancouver, British Columbia on May 12, 1938. From the computer printout it appears that 34-248481 also returned to Waukegan on May 9, 1938, though the banding office in Ottawa has no further information on this bird.

Recoveries from birds banded in Saskatchewan by Lyon and McArthur include 12 California, two Ring-billed and two Franklin's gulls, 30 Doublecrested Cormorants and 39 White Pelicans; maps for the latter two species banded at Redberry Lake are illustrated. The recovery rates of about 18 per cent for cormorants and 11 per cent for pelicans are substantially higher than the rates prevailing 
for the birds banded at the same lake in the past 12 years by this writer.

Lyon's sudden death on June 13, 1938 at the age of 63 prevented a third visit to the Saskatchewan bird colonies. Nevertheless, between 1913 and the end or 1937 he had banded 93,339 birds, many of them on his attractive three-acre grounds in Waukegan. When the Inland Bird Banding Association was formed in 1922, Lyon became its first secretary and two years later he moved up to President, an office he held until his death. Always public-spirited, he was active in Rotary and Boy Scout work particularly. The Auklet, published for the 1934 A.O.U. meeting, contains the following rhyme:

"Lyon, big Inland Bird Bander,

Is great, but not like Alexander."

We can safely conclude that he was a "big man" in every respect.

I wish to thank D. A. Benson, Canadian Wildlife Service, for information from the banding files.

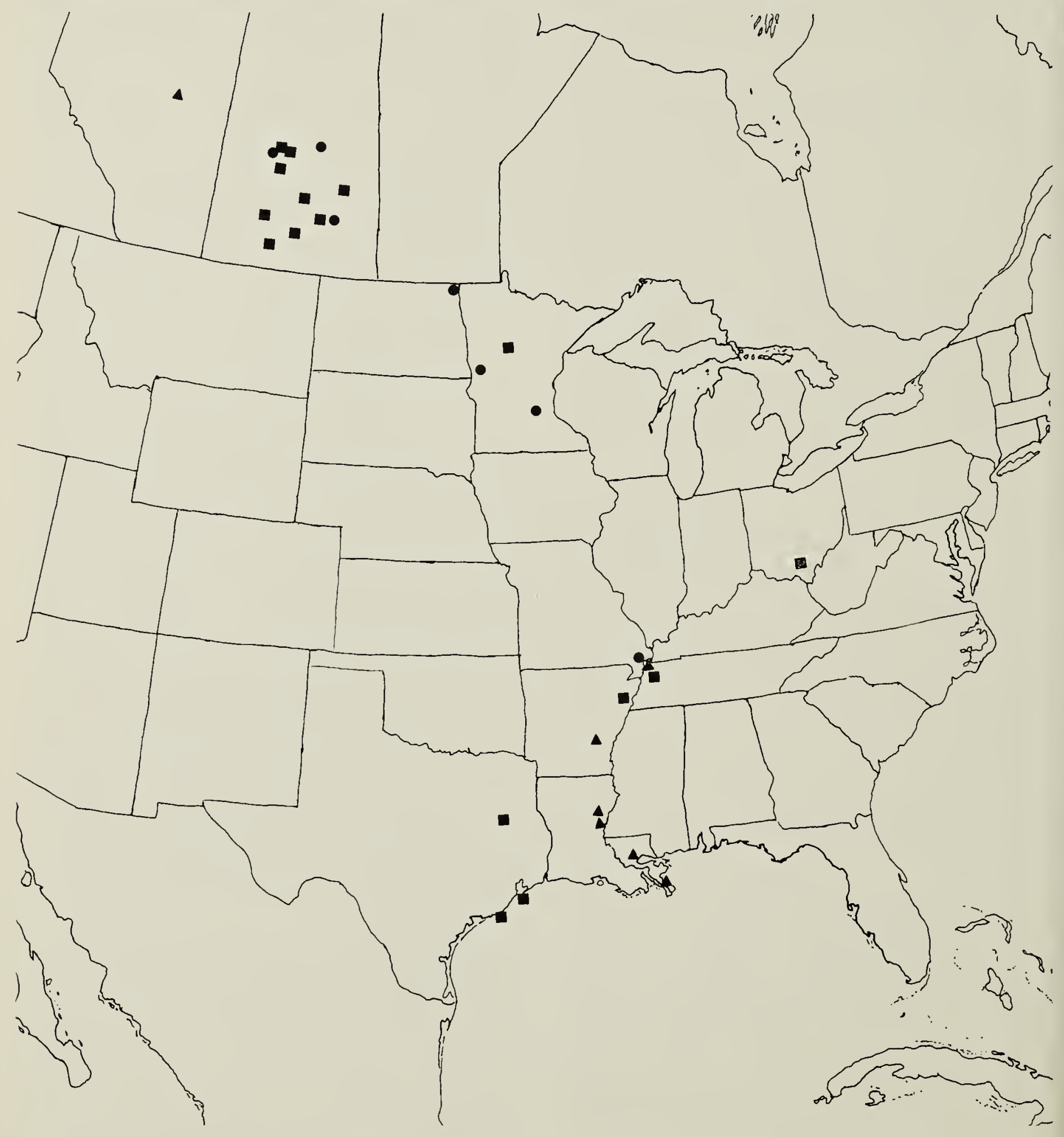

Fig. 1. Recoveries of Double-crested Cormorants banded at Redberry Lake by W. L. Lyon and H. E. McArthur. Note: Squares represent direct recoveries (same year). Triangles-January 1 to June 30 of following year. Circles-more than one year old. 


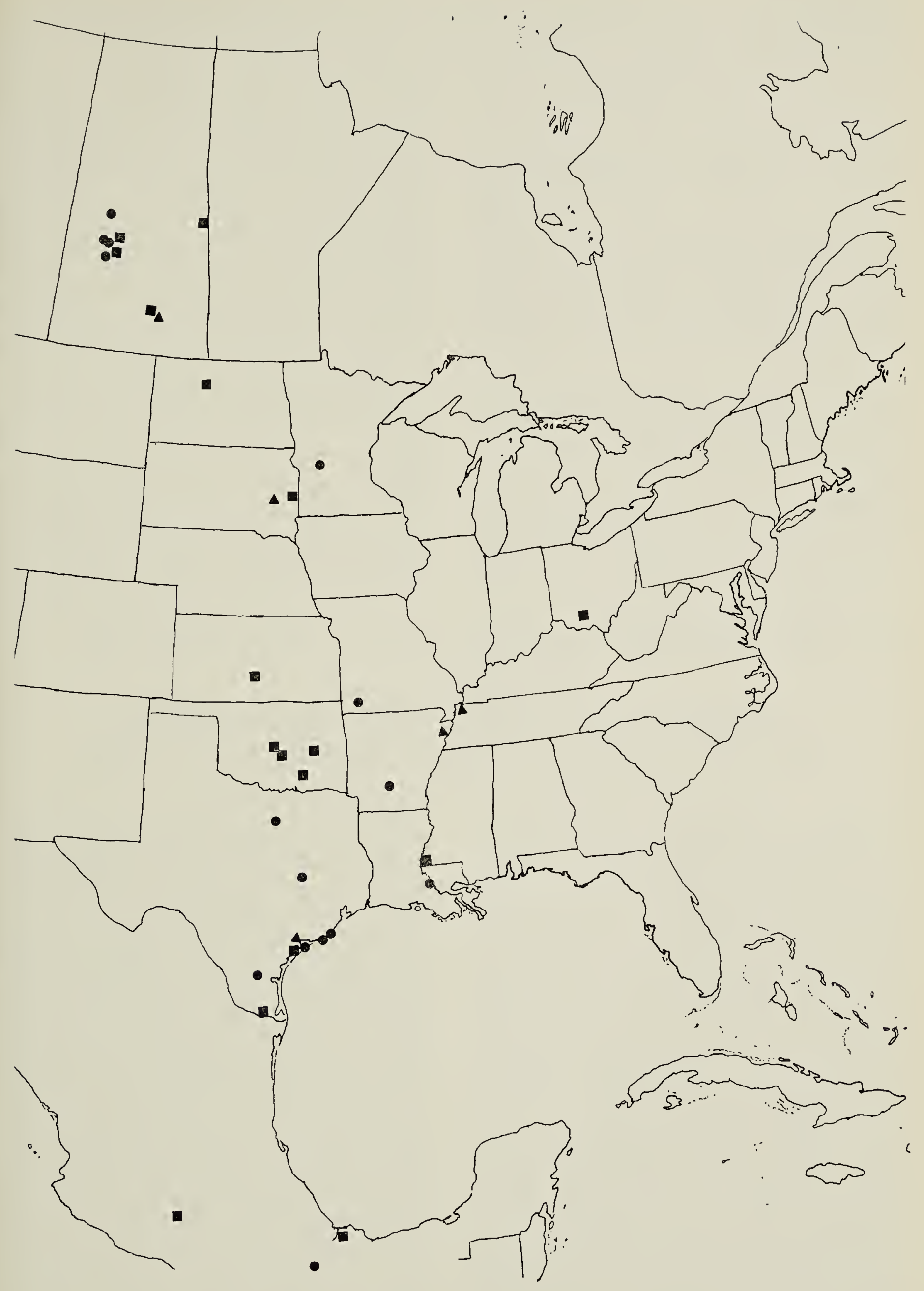

Fig. 2. Recoveries of White Pelicans banded at Redberry Lake by W. I. Lyon and H. E. McArthur. Note: Squares represent direct recoveries (same year). Triangles-January 1 to June 30 of following year. Circlesmore than one year old. 